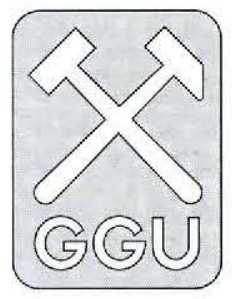

\title{
GREENMIN - Database system for the registration of Greenland mineral occurrences
}

\author{
Mogens Lind, Tapani Tukiainen and \\ Bjorn Thomassen
}

Systematic registration of economic mineral occurrences in Greenland is one of the important tasks of the Geological Survey of Greenland (GGU). GREENMIN (Greenland Mineralisation Data Bank) is the GGU database used for storing these data. The aim is to provide a broad range of exploration information in a systematic and accessible form for-use by industry and for GGU's own resource evaluation programmes (e.g. Schønwandt, 1990). Planning and design were initiated in 1987 and systematic data registration started in July 1989. Prior to the initiation of GREENMIN, GGU prepared mineral inventory compilations (including graphic presentations) mainly for internal use and for advisory tasks within the Mineral Resources Administration for Greenland.

\section{Database design}

During the design of GREENMIN existing mineral occurrence databases served as inspiration, in particular the Ore data File for Northern Finland (Gaal et al., 1977) and the MINFILE, British Columbia (Wilcox, 1988). However, as with a number of other databases available at that time, these were developed in countries with an established mining tradition and were therefore distinctly biased towards description of past/present producers and extensively explored prospects. As such information is scanty for Greenland, it was necessary to adapt the database design to the Greenlandic reality, where grass root exploration data are predominant. It was further required that administrative data could be contained in the database.

In its present form the database system is hosted by the Digital Vax/Rdb relational database management system. Report generation is heavily based on the Vax/Rally Casetool. The basic principle of the database design is to arrange information under well defined topics. The characteristic topics of the GREENMIN database are shown in Figure 1 and Table 1. The relational model has been used as the database strategy, whereby the topics on most occasions constitute the relations or tables of the database. The database is to a great extent normalised to minimise data redundancy.

The overall principle of the attribute design has been to define a collection of abbreviated valid values/codes for each attribute, which has proved successful in the design of effective, complex queries.

The extensive use of the abbreviated valid values/codes has made it necessary to create a number of 'lookup' tables containing the full description of the abbreviated valid values/codes. The purpose of these tables is two-fold in that they are used both for the validation of new data and as a repository of non-abbreviated descriptions of the items extracted from the database by the report generation tools.

In the reports and publications from which data are extracted, the mineral occurrences are typically described as case stories. To facilitate the data acquisition the concept of 'Case' has been adapted to the database design. The identifier ('code' in Fig. 2) for a discrete mineral occurrence consists of a label with two numbers designating Case and locality respectively. In its simplest form this could be illu-
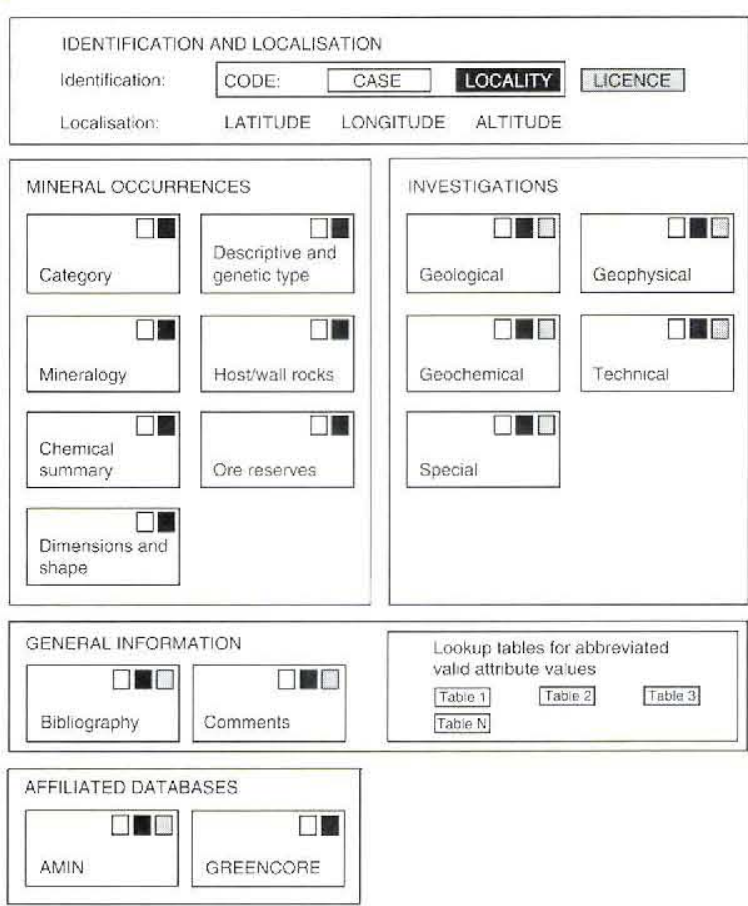

Fig. 1. Conceptual diagram of the logical structure of GREENMIN. 
strated as a mineral exploration campaign (='Case') during which a number of mineral occurrences (='localities') with common characteristics are discovered or investigated. On the other hand an exploration campaign could discover various categories of mineral occurrences which then conveniently might be described as different Cases. The Caseconcept can also be used chronologically to distinguish between the different exploration programmes dealing with the same occurrences in a given area.

The rationale of the Case/locality-concept is to avoid data redundancy by using the techniques of the relational database design. The concept also makes it possible to preserve the links between the original data sets.

In its present configuration GREENMIN is only accessible via authorised GGU staff. There are, however, a number of effective inexpensive relational database management systems available for personal computers which could accommodate the released part of GREENMIN, or selected parts of it, for more customised use in mining companies or other institutions. GGU is presently looking into the possibilities of using such personal computer database management systems for the release of data and metadata in digital form and the release of mineral occurrence maps in CGM format.

\section{Data acquisition}

Data stored in GREENMIN are compiled from industry mineral assessment reports, internal GGU reports, and published and unpublished research data. Registered mineral occurrences represent data from outcrops, drill holes or mine workings. They range from showings to trenched or drilled prospects, and include past and present producers. However, boulder finds and geochemical and geophysical anomalies are not included. The degree of detail in data registration can be inferred from Table 1 . However, it should be remembered that data quality is often affected by incomplete or inaccurate reporting. Where an interpretation of data is involved (e.g. genetic classification), this will generally reflect the opinion of the original information source, but the data compiler may occasionally have considered a re-interpretation appropriate.

By the end of 1993 the total number of localities registered was 819 , of which 602 have been released. The distribution of localities is biased towards West and South Greenland, which reflects the concentration of previous exploration in these areas.

\section{Data presentation}

Information from GREENMIN is available in tabular form and as mineral occurrence maps. Hard copy printouts can be obtained as Summary Reports and Standard Reports.
Table 1. GREENMIN information fields

Identification

GREENMIN code number

Case designation and locality name

Latitude/lóngitude/altitude

Coded/revised by, date

Mineralisation

Category

Descriptive and genetic type

Mineralogy

Ore minerals

Gangue minerals

Mineral age/method

Texture

Host/wall rocks

Rock name

Lithological association

Stratigraphic position

Relative age

Isotopic age/method

Alteration minerals

Metamorphic grade

Contact

Structure

Chemical summary

Element/mineral

Sample type and amount

Number of analyses

Average/true sampled width

Min./max./median/arithmetic mean/std.dev.

Weighted average

Distribution and number of peaks

Ore reserves

Element/mineral

Quantity and number of ore bodies

Grade

Cut-off grade

Production/until

Dimensions

Shape

Length, width and thickness

Strike/dip, trend/plunge

Inferred continuity

Investigations

Geological

Geophysical

Geochemical

Technical

Special

Bibliography

Concession data

Comments

Summary Reports provide regional reviews of mineral occurrences with selected data. The reports are in two parts with a common layout. Apart from the code each locality is described by name, geographical coordinates and deposit type. One part concerns native element, oxide 


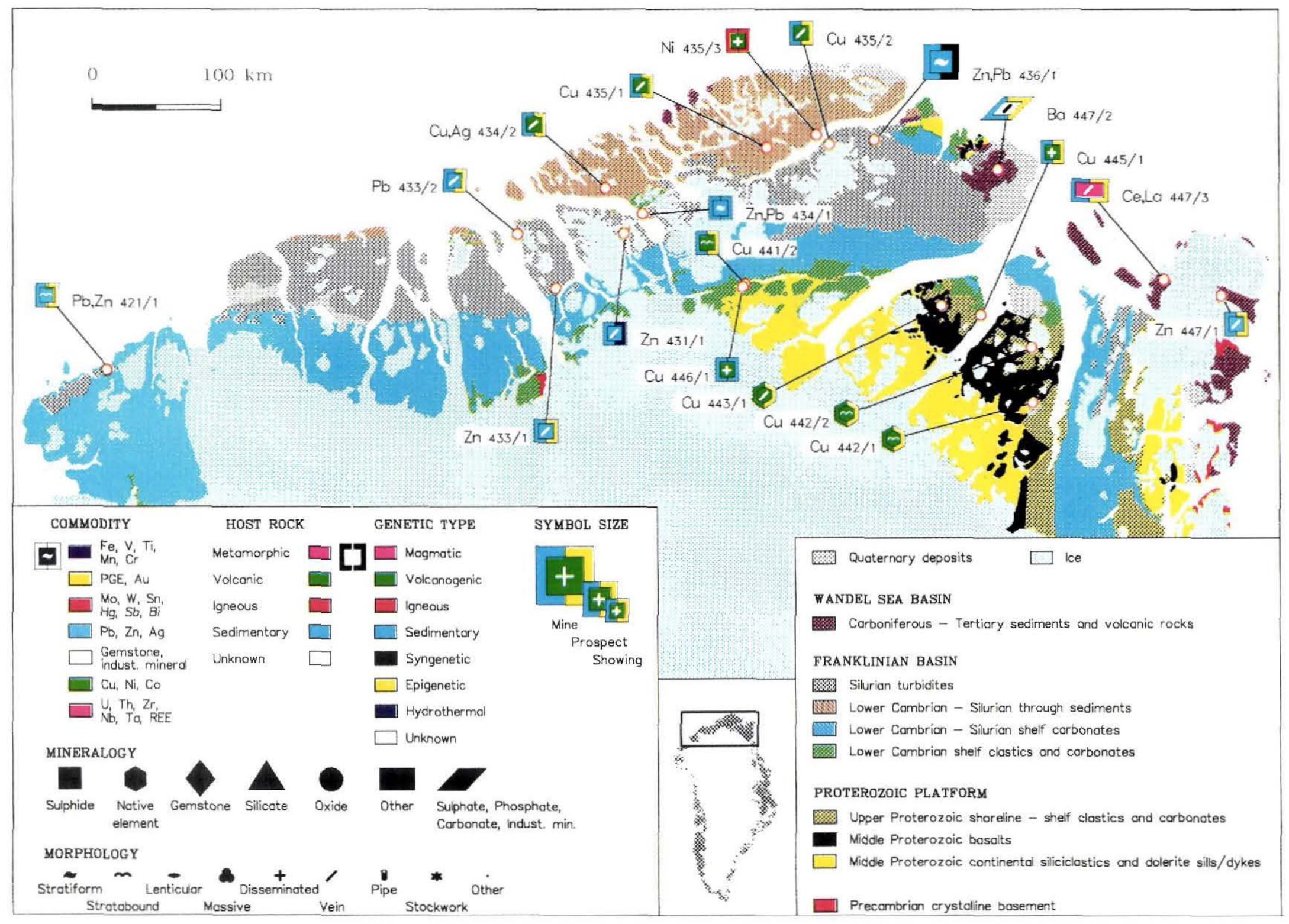


GREENMIN

Greenland Mineralisation Data Bank SUMMARY REPORT

Native element, oxide, sulphide and unspecified occurrences

\begin{tabular}{|c|c|c|c|c|c|c|c|}
\hline Code & Locality & Longitude & Latitude & Type & Origin & Commodities & $\max$ \\
\hline $421 / 1$ & Kap Schuchert & $65^{\circ} 14^{\prime} 37^{\prime \prime}$ & $80^{\circ} 47^{\prime} 05^{\prime \prime}$ & Sulphide & Epigenetic & $\begin{array}{l}\mathrm{Pb} \\
\mathrm{Zn}\end{array}$ & $\begin{array}{l}2.03 \mathrm{pct} \\
1.47 \mathrm{pct}\end{array}$ \\
\hline $431 / 1$ & Navarana Fjord vein, sulphide zone & $42^{\circ} 31^{\prime} 35^{\prime \prime}$ & $82^{\circ} 34^{\prime} 30^{\prime \prime}$ & Sulphide & Hydrothermal & $\begin{array}{l}\mathrm{Ag} \\
\mathrm{Pb} \\
\mathrm{Zn}\end{array}$ & $\begin{array}{r}60.00 \mathrm{ppm} \\
1.50 \mathrm{pct} \\
53.60 \mathrm{pct}\end{array}$ \\
\hline $433 / 1$ & Nares Land south & $45^{\circ} 55^{\prime} 00^{\prime \prime}$ & $82^{\circ} 10^{\prime} 00^{\prime \prime}$ & Sulphide & Epigenetic & & \\
\hline $433 / 2$ & Nares Land north-west & $48^{\circ} 09^{\prime} 25^{\prime \prime}$ & $22^{\circ} 30^{\prime} 08^{\prime \prime}$ & Sulphide & Epigenetic & & \\
\hline $434 / 1$ & Kap Lars Larsen & $41^{\circ} 33^{\prime} 28^{\prime \prime}$ & $82^{\circ} 42^{\prime} 53^{\prime \prime}$ & Sulphide & Sedimentary & & \\
\hline $434 / 2$ & Nansen Land & $43^{\circ} 38^{\prime} 55^{\prime \prime}$ & $82^{\circ} 52^{\prime} 45^{\prime \prime}$ & Sulphide & Epigenetic & $\begin{array}{l}\mathrm{Ag} \\
\mathrm{As} \\
\mathrm{Cu} \\
\mathrm{Sb}\end{array}$ & $\begin{array}{r}200.00 \mathrm{ppm} \\
1700.00 \mathrm{ppm} \\
1.68 \mathrm{pct} \\
1000.00 \mathrm{ppm}\end{array}$ \\
\hline $435 / 1$ & Tyr Elv & $34^{\circ} 26^{\prime} 21^{\prime \prime}$ & $83^{\circ} 08^{\prime} 27^{\prime \prime}$ & Sulphide & Epigenetic & $\begin{array}{l}\mathrm{Ag} \\
\mathrm{Cu}\end{array}$ & $\begin{array}{r}28.80 \mathrm{ppm} \\
4.99 \mathrm{pct}\end{array}$ \\
\hline $\begin{array}{l}435 / 2 \\
435 / 3\end{array}$ & $\begin{array}{l}\text { Gefion Bræ } \\
\text { Midtkap }\end{array}$ & $\begin{array}{l}30^{\circ} 48^{\prime} 55^{\prime \prime} \\
31^{\circ} 23^{\prime} 09^{\prime \prime}\end{array}$ & $\begin{array}{l}83^{\circ} 06^{\prime} 26^{\prime \prime} \\
83^{\circ} 09^{\prime} 33^{\prime \prime}\end{array}$ & $\begin{array}{l}\text { Sulphide } \\
\text { Sulphide }\end{array}$ & $\begin{array}{l}\text { Epigenetic } \\
\text { Igneous }\end{array}$ & $\mathrm{Cu}$ & $2.47 \mathrm{pct}$ \\
\hline $436 / 1$ & Citronen Fjord & $28^{\circ} 15^{\prime} 00^{\prime \prime}$ & $83^{\circ} 05^{\prime} 00^{\prime \prime}$ & Sulphide & Syngenetic & $\begin{array}{l}\mathrm{Pb} \\
\mathrm{Zn}\end{array}$ & $\begin{array}{r}5.40 \mathrm{pct} \\
12.60 \mathrm{pct}\end{array}$ \\
\hline $441 / 2$ & West of $\varnothing v$ ve Midsommers $\emptyset$ & $36^{\circ} 14^{\prime} 51^{\prime \prime}$ & $82^{\circ} 12^{\prime} 55^{\prime \prime}$ & Sulphide & Epigenetic & & \\
\hline $442 / 1$ & White Hill & $23^{\circ} 39^{\prime} 36^{\prime \prime}$ & $81^{\circ} 04^{\prime} 05^{\prime \prime}$ & Native & Epigenetic & $\mathrm{Cu}$ & $1.40 \mathrm{pct}$ \\
\hline $442 / 2$ & North Stordal & $23^{\circ} 00^{\prime} 30^{\prime \prime}$ & $81^{\circ} 25^{\prime} 50^{\prime \prime}$ & Native & Epigenetic & $\mathrm{Cu}$ & $2.00 \mathrm{pct}$ \\
\hline $443 / 1$ & Neergaard Dal & $26^{\circ} 38^{\prime} 40^{\prime \prime}$ & $81^{\circ} 52^{\prime} 15^{\prime \prime}$ & Native & Epigenetic & $\mathrm{Cu}$ & $1.08 \mathrm{pct}$ \\
\hline $445 / 1$ & Bernhard Dal & $24^{\circ} 54^{\prime} 17^{\prime \prime}$ & $81^{\circ} 44^{\prime} 34^{\prime \prime}$ & Sulphide & Epigenetic & & \\
\hline $446 / 1$ & $\emptyset$ vre Midsommers $\emptyset$ & $36^{\circ} 22^{\prime} 34^{\prime \prime}$ & $82^{\circ} 11^{\prime} 55^{\prime \prime}$ & Sulphide & Sedimentary & & \\
\hline $447 / 1$ & Kilen, Svarta Skaret & $14^{\circ} 00^{\prime} 00^{\prime \prime}$ & $81^{\circ} 17^{\prime} 00^{\prime \prime}$ & Sulphide & Epigenetic & & \\
\hline $447 / 3$ & Brecciebæk & $1610^{\prime} 00^{\prime \prime}$ & $81^{\circ} 33^{\prime} 00^{\prime \prime}$ & Unspecified & Epigenetic & & \\
\hline
\end{tabular}

Industrial mineral, silicate, gemstone and unspecified occurrences

\begin{tabular}{lllllll}
\hline Code & Locality & Longitude & Latitude & Type & Origin & Commodities \\
\hline $431 / 2$ & Navarana Fjord vein, barite zone & $42^{\circ} 31^{\prime} 35^{\prime \prime}$ & $82^{\circ} 34^{\prime} 30^{\prime \prime}$ & Industrial & Hydrothermal & Barite \\
& & $22^{\circ} 00^{\prime} 00^{\prime \prime}$ & $82^{\circ} 40^{\prime} 00^{\prime \prime}$ & Industrial & Epigenetic & Sphalerite \\
$447 / 2$ & Kim Fjelde & $16^{\circ} 10^{\prime} 00^{\prime \prime}$ & $81^{\circ} 33^{\prime} 00^{\prime \prime}$ & Unspecified & Epigenetic & Pyrite
\end{tabular}

Fig. 2. North Greenland mineral occurrence map with an example of a Summary Report for selected localities within the map area. Geological map based on Bengaard \& Henriksen (1991) and Clemmensen \& Jepsen (1992). 
and sulphide occurrences and gives commodity information by metal and best assays - providing that these attain values above a specified threshold. The second part concerns industrial minerals, silicate and gemstone occurrences and lists the main commodity minerals. An example of a Summary Report is given in Figure 2.

Standard Reports present all the data compiled for specific mineral occurrences (cf. Table 1). Data include locality name, geographical coordinates, concessionaire and period and type of investigation. Geological information comprises type and size of deposit, host and wall rocks, stratigraphy, ore/gangue/alteration minerals, chemistry, structure and resource estimate. Bibliographic information lists both published and unpublished sources, either used in the data compilation of the locality or that contain relevant information. Standard Reports may be rather voluminous and it is recommended, therefore, that Summary Reports are used to assess and select localities for which the Standard Reports are requested.

Bibliography Report. Mining companies operating in Greenland must submit reports on their exploration and exploitation activities to the Government authorities (the Mineral Resources Administration for Greenland). These reports are housed at GGU in Copenhagen and registered in the bibliographic section of GREENMIN. Each report is confidential for a period of time stated in the licence under which the work was conducted. After expiry of confidentiality, the reports are open for public inspection at GGU and as microfiche files at the Home Rule Government offices (Ministry of Trade and Industry) in Nuuk, Greenland. A bibliographic index of released industry reports can be obtained from GGU (Nielsen, 1992).

Mineral occurrence maps. Mineral occurrence maps have been included in the survey's Thematic Map Series at a scale of 1:1 000000 . Each mineral occurrence is represented by a composite symbol which conveys its characteristic genetic, mineralogical, lithological, morphological and other descriptive attributes. At present, one volume of this series has been published covering southern West Greenland (Steenfelt et al., 1990) and compilation of data for the next volume (South Greenland) is under way. An example of the symbol layout of the mineral occurrence maps is presented in Figure 2.

\section{Affiliated databases}

The geological/explorational part of GREENMIN is linked to an administrative database (AMIN) and the Greenland core library database (GREENCORE). The AMIN database is used as an internal tool for the management of GGU's administrative procedures related to prospecting and exploration licenses in Greenland.

The GREENCORE database is an inventory for $c .75000 \mathrm{~m}$ of drill core and 25000 rock and stream sediment samples from commercial exploration programmes now deposited at GGU.

Acknowledgments. To overcome the large amount of historical exploration data, the Mineral Resources Administration for Greenland provided funds for a full-time geologist and a part time librarian and secretary respectively in the start-up period. Further out-of-house contributions came from Nunaoil A/S, who offered to fill in GREENMIN data sheets for a number of localities during their own mineral inventory listing.

\section{References}

Bengaard, H.-J. \& Henriksen, N. (compilers) 1991: Geological map of North Greenland. 1:1 000 000. Bull. Grønlands geol. Unders. 160, map 1.

Clemmensen, L. B. \& Jepsen, H. F. 1992: Lithostratigraphy and geological setting of Upper Proterozoic shoreline-shelf deposits, Hagen Fjord Group, eastern North Greenland. Rapp. Grønlands geol. Unders. 157, $27 \mathrm{pp}$.

Gaal, G., Autio, H., Lehtonen, M., Mäkinen, A, Oksama, M., Saltikoff, B., Tontti, M. \& Vuorela, P. 1977: Pohjois-Suomen malmitiedostroprojekti. Summary: Ore data File Project for Northern Finland. Rep. Investig. Geol. Surv. Finland 26, 43 pp.

Nielsen, M. 1992: Bibliography. Microfiche file of Greenland mineral assessment reports by the mining industry. Internal report, Grønlands geol. Unders., 2 pp. + 4 appendices.

Schønwandt, H. K. 1990: Activities within the field of mineral resources. Rapp. Gronlands geol. Unders. 148, 37-40.

Steenfelt, A., Thorning, L. \& Tukiainen, T. 1990: Regional compilations of geoscience data from the Nuuk - Maniitsoq region, southern West Greenland. Thematic Map Ser. Gronlands geol. Unders. 90/1, 57 maps.

Wilcox, A. F. 1988: A mainframe and personal computer based mineral inventory database. British Columbia Ministry of Energy, Mines and Petrol. Res., Geol. Fieldwork, 1987, Pap. 1988$1,549-554$.

M. L., T. T. \& B. T., Geological Survey of Greenland, Copenhagen 